\title{
The Virtues of Scientific Practice: MacIntyre, Virtue Ethics, and the Historiography of Science
}

\author{
Daniel J. Hicks and Thomas A. Stapleford*
}

\begin{abstract}
"Practice" has become a ubiquitous term in the history of science, and yet historians have not always reflected on its philosophical import and especially on its potential connections with ethics. In this essay, we draw on the work of the virtue ethicist Alasdair Maclntyre to develop a theory of "communal practices" and explore how such an approach can inform the history of science, including allegations about the corruption of science by wealth or power; consideration of scientific ethics or "moral economies"; the role of values in science; the ethical distinctiveness (or not) of scientific vocations; and the relationship between history of science and the practice of science itself.
\end{abstract}

\section{Introduction}

Talk about "practice" pervades the contemporary historiography of science. In one sense, that focus has deep roots: one can find sources in continental history and philosophy of science, ${ }^{2}$ in Marxism, ${ }^{3}$ or even in the "interstitial academy" at Harvard that helped form Thomas Kuhn. ${ }^{4}$ (Despite the attention to paradigms, "practice" appears close to forty times in Structure, with Kuhn insisting that an accurate "concept of science" could come only from close study of the "research activity" of scientists.) ${ }^{5}$ Nonetheless, the term "practice" itself did not become a common analytical concept in Anglo-American historical studies of science until the mid-1970s to early 1980s, when its usage began to rise precipitously (see Figure 1). Since 2000 , almost $40 \%$ of research articles in Isis have contained five or

\footnotetext{
${ }^{*}$ Daniel J. Hicks, Science and Technology Policy Fellow, American Association for the Advancement of Science, hicks.daniel.j@gmail.com; Thomas A. Stapleford, Associate Professor, Program of Liberal Studies, University of Notre Dame, tstaplef@nd.edu. Stapleford's work on this paper was supported by the U.S. National Science Foundation under award number SES-1430854. We are very grateful for extensive comments on previous drafts from Andrew Warwick, Michael Gordin, Richard Oosterhoff, Evan Ragland, and our two anonymous reviewers. We are also indebted to Eric Lease Morgan (Hesburgh Library, University of Notre Dame), who did the programming and provided technical advice for the textual analysis in this study, as well as to Mousa Mohammadian. All views in this essay are those of the authors, and do not necessarily reflect those of any other entity or organization ${ }^{2}$ Hans-Jörg Rheinberger, An Epistemology of the Concrete: Twentieth-Century Histories of Life (Durham: Duke University Press, 2010), 1-36; Mary Jo Nye, “Historical Sources of Science-as-Social-Practice: Michael Polanyi's Berlin," Historical Studies in the Physical and Biological Sciences 37, no. 2 (March 1, 2007): 409-34.

${ }^{3}$ Dominique Lecourt, Marxism and Epistemology: Bachelard, Canguilhem, and Foucault (London: NLB, 1975); Barry Barnes, Interests and the Growth of Knowledge (London: Routledge, 1977), 70-86; Phil Gasper, "Marxism and Science," International Socialism 2, no. 79 (Summer 1998); more generally, Davide Nicolini, Practice Theory, Work, and Organization: An Introduction (Oxford: Oxford University Press, 2013), 29-33, 102-33.

4 Joel Isaac, Working Knowledge: Making the Human Sciences from Parsons to Kuhn (Cambridge: Harvard University Press, 2012).

${ }^{5}$ Thomas Kuhn, The Structure of Scientific Revolutions (Chicago: University of Chicago Press, 1996$), 1$.
} 
more sentences or citations with the terms "practice" or "practices" (see Figure 2). Caveats about brute linguistic analysis aside, "practice" has clearly become a common part of the lexicon in history of science. Similar trends in the broader field of science and technology studies sparked talk of a "practice turn," a label adopted by some historians as well. ${ }^{6}$ Indeed, a recent Isis article concluded that a "focus on practices is key" to constructing a broader, vibrant future for the history of science. ${ }^{7}$

But what theoretical work does practice accomplish? The first self-conscious efforts to make practice a core conceptual tool for studying science came primarily from scholars who linked it closely to experiments or material culture. The emphasis on experimental work flowed naturally from the social constructivist focus on activity over ideas: if you wanted to study "science in action," the theoretician's office seemed far less attractive than the buzzing, humming laboratory, and it was therefore no accident that ethnographers overwhelmingly went to labs or other sites of empirical investigation. ${ }^{8}$ Yet wasn't discourse also an action, a social practice as Wittgenstein had argued? Indeed, both Kuhn and Michel Foucault had treated scientific theorizing as a product of habitual modes of interpretation and expression inculcated through particular forms of pedagogy, ${ }^{9}$ and David Bloor's proclamation of the "strong programme" in the sociology of scientific knowledge had argued that social practice undergirded mathematics, that most arch-theoretical of disciplines. ${ }^{10}$ By the 1990 s, both historians and sociologists had begun treating theorizing itself as a social practice. ${ }^{11}$ After all, even if one thinks of theories as ideas, historians have no access to those ideas apart from how they are inscribed in practices of writing, speaking, or acting. Likewise, though we might want to say that individual scientists have ideas in their minds, scientific theories are always produced and circulated by social practices: the creation and use of texts, diagrams, and artifacts; the acts of speaking, showing, and demonstrating; and the interpretation of the same. In the end, with both theorizing and experimentation enveloped within practice, there

\footnotetext{
${ }^{6}$ e.g., Theodore R. Schatzki, Karin Knorr-Cetina, and Eike von Savigny, eds., The Practice Turn in Contemporary Theory (Routledge, 2001); Lena Soler, ed., Science after the Practice Turn in the Philosophy, History, and Social Studies of Science (New York: Routledge, 2014). For an example by a historian, see John V. Pickstone, "Working Knowledges Before and After circa 1800: Practices and Disciplines in the History of Science, Technology, and Medicine," Isis 98, no. 3 (September 1, 2007): 494-95.

${ }^{7}$ Lorraine Daston and Glenn W. Most, "History of Science and History of Philologies," Isis 106, no. 2 (2015): 378.

${ }^{8}$ Bruno Latour and Steve Woolgar, Laboratory Life: The Social Construction of Scientific Facts (London: Sage Publications, 1979); Karin Knorr-Cetina, The Manufacture of Knowledge : An Essay on the Constructivist and Contextual Nature of Science, 1st ed. . (Oxford: Pergamon Press, 1981); Michael Lynch, Art and Artifact in Laboratory Science: A Study of Shop Work and Shop Talk in a Research Laboratory (New York: Routledge \& Kegan Paul, 1985); Bruno Latour, Science in Action : How to Follow Scientists and Engineers through Society (Cambridge, Mass: Harvard University Press, 1987).

${ }^{9}$ Andrew Warwick and David Kaiser, "Kuhn, Foucault, and the Power of Pedagogy," in Pedagogy and the Practice of Science: Historical and Contemporary Perspectives, ed. David Kaiser (Cambridge: MIT Press, 2005), 393-409.

${ }^{10}$ David Bloor, "Wittgenstein and Mannheim on the Sociology of Mathematics," Studies in History and Philosophy of Science Part A 4, no. 2 (1973): 173-191.

${ }^{11}$ Eric Livingston, The Ethnomethodological Foundations of Mathematics (Boston: Routledge \& Kegan Paul, 1986); Andrew Pickering and Adam Stephanides, "Constructing Quaternions: On the Analysis of Conceptual Practice," in Science as Practice and Culture, ed. Andrew Pickering (Chicago: University of Chicago Press, 1992), 139-67; Andrew Warwick, "Cambridge mathematics and Cavendish physics: Cunningham, Campbell and Einstein's relativity, 19051911. Part I: The uses of theory. Part II: Comparing traditions in Cambridge physics," Studies in the History and Philosophy of Science A 23 (1992): 625-56.
} 
seemed to be nothing in the activities of science that was not practice; it was practice all the way down. ${ }^{12}$

In light of these shifts, practice no longer designates a particular part of science (e.g., experiments vs. ideas); science simply is a practice. Reference to practice can still carry heuristic weight, though, by indicating a particular way of looking at science: the kinds of questions one poses, the forms of evidence for which one seeks, the types of explanations one finds valuable. So what sort of heuristic is "practice"? What are the queries, forms of evidence, and explanations to which a focus on practice ought to lead us?

Over the last few decades, sociologists and philosophers have elaborated various conceptions of practice and explored their consequences for interpreting human action. ${ }^{13}$ Although historians have been less involved in these theory-laden conversations, we suggest that a closer consideration of practice might nonetheless inform the historiography of science. Rather than turning to familiar names such as Bourdieu, Foucault, or Wittgenstein, however, we have chosen a less common interlocutor: the moral and political philosopher Alasdair MacIntyre. Since the publication of After Virtue in 1981, Maclntyre has been widely recognized as one of the major moral philosophers of the twentieth century and a leader in the revival of virtue ethics; furthermore, the concept of practice plays a central role in his analyses. ${ }^{14}$ Though Macintyre's work on virtue ethics (and his associated notion of practice) has drawn less attention from science studies, ${ }^{15}$ there are several reasons why historians might find him both amenable and illuminating.

\footnotetext{
12 Andrew Pickering, ed., Science as Practice and Culture (Chicago: University of Chicago Press, 1992).

${ }^{13}$ E.g., Charles Taylor, Social Theory as Practice (New York: Oxford University Press, 1983); Joseph Rouse, Knowledge and Power: Toward a Political Philosophy of Science (Ithaca: Cornell University Press, 1987); Pickering, Science as Practice and Culture; Theodore R. Schatzki, Social Practices: A Wittgensteinian Approach to Human Activity and the Social (Cambridge: Cambridge University Press, 1996); Schatzki, Knorr-Cetina, and Savigny, The Practice Turn in Contemporary Theory; Andreas Reckwitz, "Toward a Theory of Social Practices A Development in Culturalist Theorizing," European Journal of Social Theory 5, no. 2 (May 1, 2002): 243-63; Joseph Rouse, How Scientific Practices Matter: Reclaiming Philosophical Naturalism (Chicago: University of Chicago Press, 2002); Nicolini, Practice Theory, Work, and Organization; Soler, Science after the Practice Turn in the Philosophy, History, and Social Studies of Science. All of this is in addition to foundational work by Pierre Bourdieu, Anthony Giddens, Foucault, and Wittgenstein.

${ }^{14}$ Alasdair C. Maclntyre, After Virtue: A Study in Moral Theory (Notre Dame, IN: University of Notre Dame Press, 1984). Maclntyre's subsequent work has developed themes from this book: Whose Justice? Which Rationality? (Notre Dame, IN: University of Notre Dame Press, 1988); Three Rival Versions of Moral Enquiry: Encyclopaedia, Genealogy, and Tradition (Notre Dame, IN: University of Notre Dame Press, 1990); Dependent Rational Animals: Why Human Beings Need the Virtues (Open Court Publishing, 2001).

${ }_{15}$ Notable sustained treatments of Maclntyre's virtue ethics from scholars in science studies include Stephen P. Turner, The Social Theory of Practices: Tradition, Tacit Knowledge, and Presuppositions (Chicago: University of Chicago Press, 1994); Thomas Söderqvist, "Virtue Ethics and the Historiography of Science," Danish Yearbook of Philosophy 32 (1997): 45-64; Barry Barnes, Understanding Agency: Social Theory and Responsible Action (London: Sage, 2000); Stephen P. Turner, "Maclntyre in the Province of Philosophy of Social Science," in Alasdair Maclntyre, ed. Mark C. Murphy (New York: Cambridge University Press, 2003), 70-93; J. Britt Holbrook, "What Is Interdisciplinary Communication? Reflections on the Very Idea of Disciplinary Integration," Synthese 190, no. 11 (September 25, 2012): 1865-79. The German studies scholar Chad Wellmon has also adopted Maclntyre's concept of practice for his recent study, Organizing Enlightenment: Information Overload and the Invention of the Modern Research University (Baltimore, Md.: Johns Hopkins University Press, 2015), esp. chap. 7.
} 
First, although history and philosophy of science is not the focus of Maclntyre's virtue ethics, science serves as a prominent exemplar in his writing, and he has engaged major figures such as Bachelard, Kuhn, Lakatos, Feyerabend, Polanyi, and Foucault. ${ }^{16}$ Such connections are not surprising: Maclntyre is married to the historian and philosopher of early modern science, Lynn Joy, and his work in fact shares deep intellectual resonances with those fields. From After Virtue onwards, Maclntyre has sought to define what it could mean to reason about ethics while holding to a post-foundationalist philosophy - a question that of course is closely related to post-Kuhnian debates about epistemology in the history and philosophy of science.

Second, MacIntyre's practice theory arose within his larger project to revitalize virtue ethics; practices and virtues are thus inseparable for MacIntyre. Though talk of virtue has not reached the same prominence as practice in the history of science, some scholars have begun to speak explicitly in those terms. ${ }^{17}$ More generally, historians have recognized that being a scientist does not just mean acquiring certain ideas, theoretical proficiencies, or even experimental skills; it means becoming a certain kind of person, developing specific self-conceptions, and embodying particular traits, including everything from rigorous athletic training to cultivating proper emotional responses and forms of self-presentation. ${ }^{18}$ As with practice, however, historians have generally not engaged the philosophical literature on virtue ethics or virtue epistemology in great detail; MacIntyre thus offers a productive theoretical combination.

Finally, Maclntyre has repeatedly emphasized the role of history within epistemology and ethics. Both domains are of course historical, but Maclntyre also insists that creating new epistemological and ethical practices entails constructing new historical narratives, and thus that debates about epistemology and ethics are equally debates about how to narrate the past. Such a perspective offers a fruitful view of the relationship between the history and philosophy of science: not history as a neutral repository of case studies but history as part of the arena in which epistemological and ethical struggles are and must be contested. That is, far from history being an autonomous contributor to these struggles, different modes of historical writing entail epistemological and ethical commitments, and the writing of history is thus one more domain in which these debates are enacted.

The ethical aspects of historiography extend beyond research ethics or professional codes of conduct (whether involving historians or scientists). In defining dimensions of human activity for study and analysis, historians make judgments about what is important, and these are fundamentally ethical

\footnotetext{
${ }^{16}$ Alasdair C. Maclntyre, "Epistemological Crises, Dramatic Narrative and the Philosophy of Science," The Monist 60, no. 4 (October 1, 1977): 453-72; Maclntyre, Three Rival Versions of Moral Enquiry, 17, 24, 118-22, 49-55, 20615.

17 Matthew L. Jones, The Good Life in the Scientific Revolution: Descartes, Pascal, Leibniz, and the Cultivation of Virtue (University of Chicago Press, 2006); Lorraine Daston and Peter Galison, Objectivity (Cambridge, Mass.: Zone Books, 2007); Steven Shapin, The Scientific Life: A Moral History of a Late Modern Vocation (Chicago: University of Chicago Press, 2009).

${ }^{18}$ William J. Ashworth, "The Calculating Eye: Baily, Herschel, Babbage and the Business of Astronomy," The British Journal for the History of Science 27, no. 4 (December 1, 1994): 409-41; Andrew Warwick, "Exercising the Student Body: Mathematics and Athlecticism in Victorian Cambridge," in Science Incarnate: Historical Embodiments of Natural Knowledge, ed. Christopher Lawrence and Steven Shapin (Chicago: University of Chicago Press, 1998), 288-326; Daston and Galison, Objectivity; Paul White, "Introduction: The Emotional Economy of Science," Isis 100, no. 4 (December 1, 2009): 792-97; Iwan Rhys Morus, "Placing Performance," Isis 101, no. 4 (December 1, 2010): 775-78; Jessica Wang, "Physics, Emotion, and the Scientific Self: Merle Tuve's Cold War," Historical Studies in the Natural Sciences 42, no. 5 (November 1, 2012): 341-88.
} 
judgments. (Feminist scholars have made that point repeatedly.) ${ }^{19}$ Insofar as "practice" is a heuristicinsofar as it draws our attention to certain issues, themes, or questions-it therefore offers an ethical framework that we ought to explore.

In that respect, Maclntyre's role as a moral philosopher is not irrelevant. Indeed, we will argue that a version of practice theory derived from Macintyre's work resonates with much excellent work in the history of science, and that this resonance suggests that the approach to ethics embedded in his view of practice offers a promising route for historians of science to begin thinking about the ethical commitments of their own work. Furthermore, exploring Maclntyre's practice theory may suggest promising avenues for future historiography.

Nonetheless, in this essay we do not advocate adopting Maclntyre's views tout court. Maclntyre's writing over the last three decades has attracted substantial commentary and criticism, including from scholars who reject the Thomistic framework of his later work. ${ }^{20}$ Instead, we develop a weaker version of his ethics below, one that can appeal to a pluralistic community of historians while nonetheless retaining analytic bite.

\section{A Theory of Communal Practices}

Given the extensive work on practice theory over the last four decades, practice has been defined and used in a variety of ways; ${ }^{21}$ accordingly, we have chosen to label Maclntyre's concept as communal practices in order to highlight its distinctive features. Just as "community" implies a higher degree of coherence and institutional organization than "social," Maclntyre's practices are more socially elaborate and tightly bound to groups that engage in collective projects for shared ends. Driving a car (though surely a social practice) would not constitute a communal practice for Maclntyre, but playing chess is one of his favorite examples. Both drivers and chess players are accountable to social norms (instantiated in the rules governing each activity), but chess players form a community in which they not only compete with each other but also work together to advance shared goods seen as having intrinsic value, viz., the art of playing chess. As we discuss in more detail below, we regard these kinds of goods as characteristic of communal practices. Daily commuters typically do not collaborate to produce shared goods perceived as having intrinsic value; only when drivers engage in driving as a sport (as in NASCAR, for example) can we begin to find the features of a communal practice.

Communal practices are thus a subset of the larger category of social practices. In what follows, we first briefly lay out a systematic account of the major elements of a communal practice. We then examine how this concept of communal practices supports several key ethical ideas: normativity and

\footnotetext{
${ }^{19}$ Evelyn Fox Keller and Helen E. Longino, eds., Feminism and Science (Oxford: Oxford University Press, 1996); Londa Schiebinger, Has Feminism Changed Science? (Cambridge: Harvard University Press, 2001); Angela N. H. Creager, Elizabeth Lunbeck, and Londa L. Schiebinger, eds., Feminism in Twentieth-Century Science, Technology, and Medicine (Chicago: University of Chicago Press, 2001); Maralee Mayberry, Banu Subramaniam, and Lisa H. Weasel, eds., Feminist Science Studies: A New Generation (New York: Routledge, 2001).

${ }^{20}$ E.g., Martha C. Nussbaum, "Recoiling from Reason," The New York Review of Books, December 7, 1989; John Horton and Susan Mendus, eds., After MacIntyre: Critical Perspectives on the Work of Alasdair MacIntyre (Notre Dame, IN: University of Notre Dame Press, 1994); Jeffrey Stout, Democracy and Tradition (Princeton, NJ: Princeton University Press, 2005), 118-138.

${ }^{21}$ For an overview, see Nicolini, Practice Theory, Work, and Organization.
} 
political accountability, goods or ends, and virtues. In sketching a theory of communal practices below, we have not limited ourselves to writing an exposition of MacIntyre; ${ }^{22}$ instead, this is a framework inspired by Maclntyre but inflected through other engagement with other authors. ${ }^{23}$ However, we have tried to indicate major points of divergence.

\section{Elements of a Communal Practice}

In a phrase, a communal practice is a complex, collaborative, socially organized, goal-oriented, sustained activity. ${ }^{24}$ Scientific research - including pharmaceutical research and development, paleoclimate reconstruction, economic modeling, and theoretical work in string theory - provides excellent examples of such activities. Many activities can also be understood as communal practices, including other forms of scholarship, social movements, medicine and nursing, raising and educating children, and artistic practices.

By complex we mean that a communal practice can be described in many different ways, in terms of different ontologies, at multiple levels, and in multiple "directions." Horizontally, the achievement of one line of scientific research can serve as a valuable means for other lines of research: the development of sustained nuclear reactions led to the automated liquid scintillation counter, which was a central instrument in molecular biology in the third quarter of the twentieth century. ${ }^{25}$ Vertically, the institutions of a communal practice enforce norms and provision resources, governing the actions of individuals; these norms are justified in terms of the goals of the practice.

Communal practices are collaborative, rather than individual activities. The collaborations among practitioners can be tight, as in contemporary research labs; or more diffuse, as in the early modern Republic of Letters. They will frequently require an internal politics. Practitioners will need implicit or explicit processes to settle disputes about how to provision scarce resources, how goals should be characterized, the acceptability of novel methods or techniques, how students should be trained, and so on. ${ }^{26}$ In the terminology introduced below, practitioners can disagree about both internal and external goods; and often disagreements will encompass both kinds of goods.

Looking outward, communal practices will have complex relationships with other practices, activities, and institutions. Besides internal politics, communal practices can have boundary politics, where power is used to demarcate the boundaries between inside and outside, ${ }^{27}$ and external politics, where practitioners attempt to use power to promote the interests of their practice over those of other practices, activities, and institutions. ${ }^{28}$

\footnotetext{
${ }^{22}$ For an expository introduction, see Kelvin Knight, "Practices: The Aristotelian Concept," Analyse \& Kritik: Zeitschrift Für Sozialtheorie 30, no. 2 (2008): 317-29.

${ }^{23}$ For Hicks this list includes Iris Young, Helen Longino, Janet Kourany, and Nancy Cartwright. For Stapleford, it includes Michel Foucault, Joseph Rouse, and Theodore Schatzki.

${ }^{24}$ Compare Macintyre, After Virtue, $187 \mathrm{ff}$.

${ }^{25}$ Rheinberger, An Epistemology of the Concrete, chap. 9.

${ }^{26}$ Mark Warren, “What Is Political?" Journal of Theoretical Politics 11, no. 2 (April 1999): 218.

${ }^{27}$ Michael Gordin, The Pseudoscience Wars: Immanuel Velikovsky and the Birth of the Modern Fringe (Chicago: University of Chicago Press, 2012).

${ }^{28}$ Thomas Gieryn, "Boundary-Work and the Demarcation of Science from Non-Science: Strains and Interests in Professional Ideologies of Scientists," American Sociological Review 48, no. 6 (December 1983): 781-95.
} 
Drawing on discussions in philosophy of science, it's plausible to think the constitutive ends or goals of science, taken generally, are both epistemic and pragmatic. That is, research aims both at knowledge (prediction, understanding) and pragmatic action outside the domain of the practice itself. For some analytical purposes, it may be useful to view different fields as having different emphases: perhaps areas of cosmology have primarily epistemic aims, with no immediate practical application beyond the extension of cosmology; while the aims of biomedical research are primarily pragmatic; and research on genetically modified crops is a mix of both.

Multiple scales or differences in temporal scope can be a useful way of thinking about communal practices and their constituent activities. Specifically, spatially or temporally "small" actions can be explained by understanding them as contributions to "larger" activities. For example, suppose a researcher is using a pipette to transfer a small quantity of liquid from one container to another. She might explain this action by showing how it constitutes one small part of an experiment; which in turn helps constitute an experiment being conducted by her lab; which in turn helps constitute a larger research program; which in turn hopes to develop a treatment for some disease; and so in turn aims to promote human well-being more generally. ${ }^{29}$ (Of course, whether or not the research program actually succeeds in promoting human well-being is another question, and other members of the project might embed these actions within different narratives with different goals, such as gaining status for the lab or making a profit for a company.)

Communal practices can appear to be stable or unchanging at some physical or temporal scales even as they are undergoing radical changes at other scales. For example, the development of genomics and epigenetics from late-twentieth-century genetics has involved radical conceptual changes, but at the level of laboratory activities the differences are arguably relatively subtle. ${ }^{30}$ By contrast, the development of "Big Data" is causing radical changes in day-to-day research activities in many fields of biomedical and social science, and specifically will require significant changes to standard statistical techniques, but arguably without requiring significant changes at the level of theoretical frameworks or philosophical accounts of the relationship between evidence and theory. ${ }^{31}$

\section{Normativity and Accountability}

Because communal practices are collaborative, organized, and goal-oriented, they have a normative structure at both the individual and group level. This normativity may be partially embodied by explicit rules, such as the guidelines for conducting an ethically and epistemologically rigorous series of clinical

\footnotetext{
${ }^{29}$ Maclntyre, After Virtue, 206ff; Michael Thompson, Life and Action (Cambridge, MA: Harvard University Press, 2010).

${ }^{30}$ Christine Hine, "Databases as Scientific Instruments and Their Role in the Ordering of Scientific Work," Social Studies of Science 36, no. 2 (April 2006): 269-98; Sarah Richardson and Hallam Stevens, eds., Postgenomics: Perspectives on Biology After the Genome (Durham; London: Duke University Press, 2015).

${ }^{31}$ Sabina Leonelli, "What Difference Does Quantity Make? On the Epistemology of Big Data in Biology," Big Data \& Society, June 3, 2014; Jianqing Fan, Fang Han, and Han Liu, "Challenges of Big Data Analysis," National Science Review 1, no. 2 (June 1, 2014): 293-314; Emanuele Ratti, "Big Data Biology: Between Eliminative Inferences and Exploratory Experiments," Philosophy of Science 82, no. 2 (April 2015): 198-218.
} 
trials in pharmaceutical research. However, there are deep philosophical reasons to think that norms must also take other forms, such as concrete models of excellent (or poor) behavior. ${ }^{32}$

Norms can be introduced and enforced from "outside" of the practice: the US Federal "Common Rule" (45 CFR part 46) regulates the use of human subjects in clinical research, for example. However, norms can also develop and be enforced among practitioners themselves. ${ }^{33}$ Practitioners, as practitioners, hold each other accountable to certain norms. Practitioners who fail to meet these norms are (or should be) punished by their peers, perhaps by being deprived of important resources, power, or status; or, in more severe cases, by being marginalized or denied membership in the community of practitioners. Inversely, practitioners who do well according to these norms are (or should be) rewarded, often by being given more resources, power, or status.

Though practices are normative, practitioners need not share the same norms or interpretations of those norms in order to remain part of the same practice. Instead, the crucial feature is the operation of accountability and its politics. ${ }^{34}$ As Joseph Rouse argues, practices are characterized fundamentally not by shared rules, but by accountability among practitioners. Different lab groups may disagree substantially about what constitutes good research on gravitational waves, ${ }^{35}$ but they are held together as a communal practice by being subject to evaluation from other practitioners. Should the differences grow too great, the practice might fragment, with subgroups limiting the extent to which they are accountable to their former colleagues. Cosmologists are (partially) accountable to quantum theorists, and internally hold each other accountable to this external authority. They hold no such truck with astrologers, and it would take either action by an external authority or an internal political upheaval literally, a revolution in the (largely informal) institutions governing cosmology - to render cosmologists accountable to astrologers. This shows the tight connection between normativity and accountability: the norms of cosmology are the rules and standards to which cosmologists are held accountable, whether by external authorities or among themselves. Thus, the boundaries of communal practices are established sociologically and politically (Who is accountable to whom, and for what actions?) rather than by an underlying philosophical unity (Do these individuals share precisely the same norms and the same interpretation of them?). Obviously, practitioners will compare norms when deliberating about the boundaries of accountability, but ultimately those decisions about accountability will define the boundaries of the practice. Accordingly, the norms in a practice may be like the "family resemblances" described by Wittgenstein: each practitioner's norms might share some commonalities or close

\footnotetext{
32Ludwig Wittgenstein, Philosophical Investigations, trans. G.E.M. Anscombe (1953; repr., Malden, MA; Oxford: Blackwell Publishing, 2001), sec. 185ff; Michael Polanyi, The Tacit Dimension (University of Chicago Press, 1966); Maclntyre, "Epistemological Crises, Dramatic Narrative and the Philosophy of Science"; see also Harry Collins and Robert Evans, Rethinking Expertise (Chicago; London: University of Chicago Press, 2007) ch. 1.

${ }^{33}$ Joseph Rouse, "Practice Theory," in Handbook of the Philosophy of Science, Vol. 15: The Philosophy of Sociology and Anthropology, ed. S. Turner and M. Risjord (Elsevier, 2006), 639-81; Joseph Rouse, "Social Practices and Normativity," Philosophy of the Social Sciences 37, no. 1 (March 2007): 46-56.

${ }^{34}$ Ernan McMullin, "Values in Science," in PSA 1982: Proceedings of the 1982 Biennial Meeting of the Philosophy of Science Association, ed. Peter Asquith and Thomas Nickles, vol. 2 (Philosophy of Science Association, 1983), 5-6; Rouse, How Scientific Practices Matter.

${ }^{35}$ Harry M. Collins and Trevor J. Pinch, The Golem : What Everyone Should Know about Science (Cambridge: Cambridge University Press, 1993), 91-107.
} 
resemblances to others, but no single group of norms may demarcate the precise bounds of the practice.

Because communal practices are maintained sociologically and politically in this way, we should expect repeated and continual conflict over the norms: that is (in the case of science) arguments over what constitutes good knowledge, what techniques or methods are appropriate for producing that knowledge, and what characteristics are needed to be a good scientist. Moreover, we should expect the contours of these arguments-the themes, core issues, areas of tacit consensus or key points of dispute-to shift over time.

This historicism distinguishes MacIntyre's view from Robert Merton's famous consideration of the "values and norms...held to be binding on the man of science." Merton treated science as an ahistorical ideal with fixed goals, namely those he ascribed to mid-twentieth century science in liberal democracies. ${ }^{36}$ Consequently, his comparative sociology of science, ethics, and culture focused on holding other practices (notably Nazi Germany and Soviet Russia) up to this fixed yardstick. By contrast, the framework of communal practices that we sketch here requires empirical work to understand how the specific aims and norms of any given particular scientific practice fit together and relate to the particular social, historical, and geographical context. (Such historicism does not, of course, preclude us from making our own ethical judgments about the relative merits of these different practices.)

Goods

The goals of a communal practice are characterized as what Maclntyre calls goods of excellence or internal goods, by contrast with goods of efficiency or external goods. ${ }^{37}$ In After Virtue, internal goods are defined as those that can only be achieved through proper engagement with a particular communal practice; I can develop a new model for protein folding only by participating in the practice of biochemistry. By contrast, external goods such as power, money, or status can be obtained through a variety of means. ${ }^{38}$ In Maclntyre's later terminology, internal goods are "goods of excellence" whereas external goods are "goods of efficiency" - they are purely instrumental, means for reaching an end. Maclntyre recognizes that both types of goods are, indeed, good things to have. Money is necessary to pay for research equipment, status is necessary to recruit lab assistants, and so on. But there are ethically significant, qualitative differences between them, and so it is a deep category mistake to think, for example, that the internal goods of scientific practice can be measured entirely in terms of their market value. ${ }^{39}$

Taking MacIntyre's widely-spread discussions of these two types of goods as a whole, they can be distinguished by four features: goods of excellence are collective, intrinsically valuable, integrated, and progressive. ${ }^{40}$ Goods of excellence are collective because (unlike money, power, or status) my possession of them does not inhibit you from possessing them to the same degree; moreover, by

\footnotetext{
${ }^{36}$ Robert K. Merton, "A Note on Science and Democracy," Journal of Legal and Political Sociology 1 (October 1942): 116; Robert K. Merton, “Science and the Social Order," Philosophy of Science 5, no. 3 (1938): 321-37.

${ }^{37}$ MacIntyre, After Virtue, 187ff; Alasdair Maclntyre, Whose Justice? Which Rationality?, ch. 3.

${ }^{38}$ Macintyre, After Virtue, 188-89.

${ }^{39}$ Compare Elizabeth Anderson, Value in Ethics and Economics (Harvard University Press, 1993).

${ }^{40}$ These terms are ours rather than Macintyre's, but they reflect an attempt to synthesize key elements of his arguments.
} 
obtaining these goods I enhance the scope or development of the practice as a whole. The excellence of synthesizing a new compound does not prevent someone else from synthesizing that same compound, and if I share my knowledge with the community, I have advanced the practice as a whole. Of course, I could choose to keep my knowledge secret so as reap greater monetary rewards - but in that case, I am treating the synthesis as a "good of efficiency," as a means to other ends. Similarly, if I claim intellectual property rights - or sell those rights to someone else - and legally prohibit you from synthesizing the compound, I am limiting the collective value of my work for the sake of financial gain. ${ }^{41}$

If goods of efficiency are characterized as means to an end, then goods of excellence must be ends in themselves; that is, they must have intrinsic value, at least according to the norms of the practice. For example, some areas of scientific research - especially ones with no obvious practical applications - are often justified by appeals to "curiosity." ${ }^{22}$ We suggest that these appeals can be read as assertions that pursuing such understanding is valuable for its own sake, independently of its value for achieving other goods. ${ }^{43}$ Even when the pursuit of understanding is unsuccessful or fails to be useful for other, non-scientific ends, it still has value, and indeed sufficient value - according to these appeals - to justify devoting significant resources towards the pursuit.

Intrinsic value does not define the boundary between "basic" and "applied" science, much less between science and technology. Aerospace engineers designing sleek, functional, and efficient aircraft may describe the excitement of having exercised and challenged their rational and creative powers, of having brought something novel and beautiful into the world and extended human capabilities.

Excellent design and construction, they might argue, have intrinsic value.

Furthermore, goods with intrinsic value may also have instrumental value; i.e., they may also be valuable as means to realize other ends. An understanding of the quantum mechanical behavior of electrons in semiconductors can both satisfy the curiosity of researchers and be instrumentally valuable for building transistors and possibly for bringing money and status to a lab. ${ }^{44}$ However, to claim that a good has intrinsic value means that its worth is not exhausted by or reduced to its instrumental value.

The notion of intrinsic value is philosophically controversial. ${ }^{45}$ However, some of the controversy can be avoided by replacing the metaphysically loaded, standard conception of intrinsic value - having value grounded "in itself" - with a social or political conception: X has intrinsic value for practitioners if, and only if, they cannot reject the claim that $X$ is valuable and worth pursuing on the grounds that $X$ has no value for other, further ends. Of course, not all participants in a given practice may agree on what has intrinsic value; perhaps some look to Y or Z. Again, sorting out these disagreements requires politics.

\footnotetext{
41 Tania Simoncelli and Sandra S. Park, "Making the Case Against Gene Patents," Perspectives on Science 23, no. 1 (June 30, 2014): 106-45.

${ }^{42}$ D.E. Berlyne, "Curiosity and Exploration," Science 153, no. 3731 (July 1, 1966): 25-33; Lorraine Daston, "Curiosity in Early Modern Science," Word and Image 11, no. 4 (October 1995): 391-404; Lorraine Daston and Katharine Park, Wonders and the Order of Nature, 1150-1750 (Zone Books, 2001); Sybille van den Hove, "A Rationale for Science-Policy Interfaces," Futures 39, no. 7 (September 2007): 807-26.

${ }^{43}$ Michael J. Zimmerman, "Intrinsic Vs. Extrinsic Value," in The Stanford Encyclopedia of Philosophy, ed. Edward N. Zalta, Spring 2015 edition, 2015, http://plato.stanford.edu/archives/spr2015/entries/value-intrinsic-extrinsic/. ${ }^{44}$ Lillian Hoddeson and Michael Riordan, Crystal Fire: The Invention of the Transistor and the Birth of the Information Age (New York; London: Norton, 1997).

${ }^{45} Z$ immerman, "Intrinsic Vs. Extrinsic Value."
} 
Naturally, even within a communal practice, not all sub-practices will necessarily be treated as having intrinsic value: skilled glass-blowing became an essential aspect of nineteenth-century organic chemistry, ${ }^{46}$ but some chemists may have regarded it as a tedious task, valuable only as a means to produce proper instruments and not in itself. Context, of course, is key: the practice of glass-blowing has intrinsic value for those who see it as an art form. Whether or not some activity or artifact constitutes a good of excellence, therefore, is relative to a particular larger practice in which it is embedded (art versus nineteenth century chemistry, in this example) and the view of participants.

If intrinsic value is defined sociologically-these are the goods that participants value as ends-inthemselves - we seem to have reached a block in our effort to render practices intelligible: why should participants regard certain ends as intrinsically valuable but not others? Here, the integrated character of goods of excellence comes into play. Briefly, goods of excellence have intrinsic value because they are integrated into broader conceptions of what constitutes a meaningful life, a form of human excellence, or a worthy mode of being-in-the-world. This topic requires more exploration, and we will take it up in greater depth below (Virtues and the Ethos of Science). Suffice it to say for now that the intrinsic value of the goods of a practice is best understood in the context of a richer array of practices that ground such a pursuit as being valuable "in itself."

We can illustrate the progressive aspect of goods of excellence by considering efforts to increase the predictive power of scientific knowledge. The successful pursuit of understanding and predictive power is progressive on at least two levels. First, as scientific research is conducted, it gradually produces more understanding and better predictions. (We consider Kuhnian objections to this point in the next paragraph.) In addition, scientists improve their ability to engage in these pursuits: there is development and refinement in research methods, and scientists' and philosophers' conceptions of understanding and prediction are themselves improved. For example, pharmaceutical research seeks not only to develop new drugs, but also to improve the experimental and statistical methods by which new drugs are developed. This second-order progress is itself a distinct good of excellence of the practice. ${ }^{47}$ At both levels, progress is often achieved "dialectically," through critical exchange between advocates of different points of view; ${ }^{48}$ consider the emergence of quantum theory in part from the debate between wave and particle theorists of light.

Progress is not inevitable. Communal practices can stagnate or degenerate, failing to make progress or even undoing prior progress. ${ }^{49}$ Furthermore, changes at the second level can modify practitioners' assessment of changes at the first level. In more familiar language from Kuhn: as a result of paradigm change, what was previously seen as progressive normal science is now seen as limited, unproductive, or misdirected. For example, for much of the nineteenth and twentieth century, scientific progress was understood in a highly totalizing way, as the discovery of mathematical "laws" that would eventually be reduced to a single set of "fundamental laws." Today, by both scientists in many fields and

\footnotetext{
${ }^{46}$ Catherine M. Jackson, "The 'Wonderful Properties of Glass': Liebig's Kaliapparat and the Practice of Chemistry in Glass," Isis 106, no. 1 (March 1, 2015): 43-69.

${ }^{47}$ Maclntyre, Whose Justice? Which Rationality?, 31.

${ }^{48}$ Talbot Brewer, The Retrieval of Ethics (Oxford; New York: Oxford University Press, 2011) chs. 2 and 3.

${ }^{49}$ MacIntyre, Three Rival Versions of Moral Enquiry, chap. 7; Alasdair Maclntyre, "Some Enlightenment Projects Reconsidered," in Selected Essays: Ethics and Politics, by Alasdair Maclntyre (1995; repr., Cambridge: Cambridge University Press, 2006), 172-85.
} 
many philosophers of science, scientific progress is understood in a radically piecemeal way, as the construction of local models for very specific systems, often but not necessarily mathematical, combining both generalizations and ad hoc adjustments, and with reference to the anticipated practical uses for the model. ${ }^{50}$

Although goods of efficiency (such as power, money, or status) fail to meet the criteria of goods of excellence (lacking at least one of collectiveness, intrinsic value, integration, and progressiveness), MacIntyre nonetheless insists that such goods are legitimate and indeed valuable as resources or means to pursue goods of excellence. However, there is always a temptation to reverse this, for example, by treating the goods of the practice as mere means to wealth. The institutions that surround a communal practice - university hierarchies, industry and government funders - generally should (according to the norms of the practice) provision these resources in ways that promote the achievement of the practice's goods of excellence. However, in cases of institutional domination, resources are provisioned in ways that enable the institution or its members to acquire still more resources, but at the expense of achieving goods of excellence. This is arguably the case with commodified pharmaceutical research: in pursuit of profit, the pharmaceutical industry has come to dominate pharmaceutical research, to the extent that genuinely excellent achievements in research and the promotion of human health are being sacrificed. ${ }^{51}$ We will return to this tension between goods of excellence and goods of efficiency in a later section.

\section{Virtues}

In After Virtue, Maclntyre introduces his theory of communal practices to reveal the nature and function of virtues. ${ }^{52}$ Once we understand the normative character of communal practices, we can recognize that participants must have certain qualities of character in order to realize its goods of excellence. Drawing on Aristotle, Maclntyre theorizes these qualities as virtues: dispositions to think, act, and feel in ways that exemplify the models of excellence in the practice and allow it to be sustained and advanced.

Since the discussions of virtue by ethicists often differ from contemporary colloquial usage, a few clarifications are in order. First, virtues in the Aristotelian sense are not limited to what we might call "moral" virtues. The Greek term translated as "virtue," aretē, means "excellence". ${ }^{53}$ The virtuous practitioner, in this respect, is the excellent practitioner, the one whose qualities allow her to routinely realize the goods of the practice. Aristotelian virtues are thus the qualities of excellence in a practice; they may refer to how the practitioner relates to her environment (including other practitioners), how she assesses the concrete situation in which she finds herself, or how she reacts to that assessment. Many of these qualities may have no bearing on what we commonly identify as "moral": the virtuous (excellent) long-distance runner, for example, must exhibit endurance in the face of pain, a trait that is surely admirable but rarely considered "moral".

\footnotetext{
${ }^{50}$ Some classical discussions include John Dupré, The Disorder of Things: Metaphysical Foundations of the Disunity of Science (Harvard University Press, 1995); Nancy Cartwright, The Dappled World (Cambridge, UK: Cambridge University Press, 1999); Mary Morgan and Margaret Morrison, eds., Models as Mediators: Perspectives on Natural and Social Sciences (Cambridge University Press, 1999); Michael Weisberg, "Forty Years of 'the Strategy': Levins on Model Building and Idealization," Biology and Philosophy 21, no. 5 (2006): 623-45.

${ }^{51}$ Compare Daniel Hicks, "A New Direction for Science and Values," Synthese 191, no. 14 (2014): sec. 6.

52 Maclntyre, After Virtue, $186 \mathrm{ff}$.

${ }^{53}$ For Maclntyre's explication of Greek notions of virtue, see MacIntyre, Whose Justice?, 12-145.
} 
Second, virtues may build upon existing tendencies, but they are nonetheless acquired traits. Becoming virtuous requires building dispositions or habits to act in certain ways, which requires emulation, repetition, and correction. Virtue is learned "through practice," in at least two senses. First, virtue is learned by practicing being virtuous, rather than a primarily intellectual process of reflecting on moral duties or calculating aggregate utilities. For many virtue ethicists, virtues are cultivated before they are understood; we learn habits of honesty starting as toddlers, and only later do we learn why honesty is a valuable habit. ${ }^{54}$ Second, virtue is learned in and through our relationships with others, in our communal practices. Paradigmatically, as novices in a communal practice we emulate our teachers and mentors, and receive feedback from them that helps correct our behavior. Consequently, the social relations and institutions that are part of a communal practice must facilitate the emulation, repetition, and correction of its virtues. Historians and sociologists of science have shown that scientific training involves exactly this process of emulation, repetition, and correction. ${ }^{55}$

Third, unlike some contemporary uses of "habit," virtues are not routines, actions or series of actions that are performed automatically. Julia Annas makes this point by likening virtues to skills, such as playing the piano. ${ }^{56} \mathrm{~A}$ skilled pianist has cultivated certain skillful habits through many hours of emulation and repetition, such as fingerings for standard scales and arpeggios. The pianist can indeed play these with little conscious thought or attention. But that mindlessness enables her to direct her attention to other, more artistically significant aspects of her playing: "better ways of dealing with transitions between loud and soft, more subtle interpretations of the music, and so on." This conscious artistry, in turn, shapes the way she plays the scales and arpeggios, so that even these habits are not exercised as mere routines. In the same way, virtues are habits that "enable us to respond in creative and imaginative ways to new challenges." 57

Finally, in a departure from Maclntyre, we adopt a weaker approach in which virtues are always relative to a practice. Thus a virtue in one practice may be indifferent, or even vicious, in another. ${ }^{58}$ For example, some feminist standpoint theorists argue that a degree of sympathetic identification with one's research subjects is essential for good social science, and perhaps even in fields such as corn genetics, ${ }^{59}$ but this sympathy conflicts sharply with prevailing notions of objectivity as detached and

\footnotetext{
${ }^{54}$ Aristotle, Nicomachean Ethics, II.3.1104b11-12; Rosalind Hursthouse, On Virtue Ethics (Oxford: Oxford University Press, 1999), chap. 5.

55 Jed Z. Buchwald, Scientific Practice: Theories and Stories of Doing Physics (University of Chicago Press, 1995); Andrew Warwick, Masters of Theory: Cambridge and the Rise of Mathematical Physics (University of Chicago Press, 2003); David Kaiser, Pedagogy and the Practice of Science: Historical and Contemporary Perspectives (MIT Press, 2005).

56 Julia Annas, Intelligent Virtue (Oxford: Oxford University Press, 2011), chs. 2-3.

57 Ibid., 14, 15.

${ }^{58}$ Maclntyre would qualify this relativism on at least two grounds. First, because Maclntyre insists on the integrative character of communal practices, he would argue that a coherent life must strive to overcome conflicting notions of virtue. To engage in two conflicting practices without seeing that conflict as a problem would, for Macintyre, mean that one has ultimately failed to be truly virtuous. Second, in later work, Maclntyre has attempted to build an empirical grounding for human virtue: see Maclntyre, Dependent Rational Animals. ${ }^{59}$ Evelyn Fox Keller, A Feeling for the Organism: The Life and Work of Barbara McClintock (San Francisco: W. H. Freeman, 1983); Joyce Ladner, "Introduction to Tomorrow's Tomorrow: The Black Woman," in The Gender of Science, ed. Janet A. Kourany (Upper Saddle River, NJ: Prentice Hall, 2002), 353-60.
} 
disinterested. ${ }^{60} \mathrm{~A}$ theory of communal practices, therefore, does not provide us with a full ethical theory. It distinguishes between goods of excellence and goods of efficiency, but does not on its own terms help us to differentiate between various goods of excellence that might be proposed.

\section{Communal Practices and the Historiography of Science}

The concept of communal practices offers a rich and flexible ethical framework for understanding science as a particular form of human activity. To illustrate its ramifications for historiography, we have chosen to focus on five examples that touch on prominent issues in the history of science: allegations about the corruption of science by wealth or power; consideration of scientific ethics or "moral economies"; the role of values in science; the ethical distinctiveness (or not) of scientific vocations; and the relationship between history of science and the practice of science itself.

\section{Virtues and the Corruption of Science}

Historians are familiar with laments about the corruption of science by the desire for wealth or prestige. Today, of course, fears about the commercialization of scientific research are common; ${ }^{61}$ fifty years ago, military funding took center stage. ${ }^{62}$ Back in the nineteenth century, calls to preserve "pure science" emphasized the dangers of serving industrial or commercial interests. ${ }^{63}$ Going back even further, aristocrats of seventeenth century England sometimes doubted the reliability of those perceived to lack economic or social independence (such as women, servants, or merchants), a gentlemanly code that Steven Shapin has argued affected natural philosophy as well. ${ }^{64}$

Though historians have usually taken recent threats to scientific integrity seriously, ${ }^{65}$ they have also recognized that money or status have long been entangled with science. For example, nineteenth-

\footnotetext{
${ }^{60}$ Catherine Jordan, Gust, and Naomi Scheman, "The Trustworthiness of Research: The Paradigm of CommunityBased Research," in Shifting Ground: Knowledge and Reality, Transgression and Trustworthiness, ed. Naomi Scheman (New York: Oxford University Press, 2011), 170-90.

${ }^{61}$ E.g., Derek C. Bok, Universities in the Marketplace: The Commercialization of Higher Education (Princeton: Princeton University Press, 2003); Daniel Lee Kleinman, Impure Cultures: University Biology and the World of Commerce (Madison, Wis.: University of Wisconsin Press, 2003); Sheldon Krimsky, Science in the Private Interest: Has the Lure of Profits Corrupted Biomedical Research? (Lanham: Rowman \& Littlefield Publishers, 2003).

62 Paul Forman, "Behind Quantum Electronics: National Security as Basis for Physical Research in the United States, 1940-1960," Historical Studies in the Physical and Biological Sciences 18, no. 1 (1987): 149-229; Dan Kevles, "Cold War and Hot Physics: Science, Security, and the American State, 1945-56," Historical Studies in the Physical and Biological Sciences 20, no. 2 (1990): 239-64; Mark Solovey, "Project Camelot and the 1960s Epistemological Revolution: Rethinking the Politics-Patronage-Social Science Nexus," Social Studies of Science 31, no. 2 (2001): 171-206; Joy Rohde, Armed with Expertise: The Militarization of American Social Research during the Cold War (Ithaca: Cornell University Press, 2013).

${ }^{63}$ Michael Aaron Dennis, "Accounting for Research: New Histories of Corporate Laboratories and the Social History of American Science," Social Studies of Science 17, no. 3 (August 1, 1987): 479-518; Paul Lucier, "The Origins of Pure and Applied Science in Gilded Age America," Isis 103, no. 3 (September 1, 2012): 527-36.

${ }^{64}$ Steven Shapin, A Social History of Truth: Civility and Science in Seventeenth-Century England (Chicago: University of Chicago Press, 1994), 86-95. For further debate on this issue, see Mordechai Feingold, "When Facts Matter," Isis 87, no. 1 (1996): 131-39; John A. Schuster and Alan B. H. Taylor, "Blind Trust: The Gentlemanly Origins of Experimental Science," Social Studies of Science 27, no. 3 (1997): 503-36.

${ }^{65}$ Consider Allan Brandt, The Cigarette Century: The Rise, Fall, and Deadly Persistence of the Product That Defined America (New York: Basic Books, 2009); Naomi Oreskes and Erik M. Conway, Merchants of Doubt: How a Handful
} 
century chemists, geologists, and physicists built profitable connections to burgeoning industries, ${ }^{66}$ and even in earlier periods the pursuit of natural philosophy could offer prestige or power. After all, Galileo used his mathematical and philosophical pursuits to build patronage networks, while Newton and Leibniz taunted one another repeatedly in their priority dispute over calculus. ${ }^{67}$ Mertonian norms aside, it seems that scientists have always been self-interested; only the form of that self-interest has changed. As Steven Shapin concluded after his own assessment of debates over "commercialization" in higher education, "Throughout history, all sorts of universities have 'served society' in all sorts of ways, and, while market opportunities are relatively novel, they do not compromise academic freedom in a way that is qualitatively distinct from the religious and political obligations that the ivory tower universities of the past owed to the powers in their societies." ${ }^{68}$

The major practice theorist Pierre Bourdieu takes an even more striking view of commercialization. For Bourdieu, practices are lower-level phenomena that are both situated within and help to constitute larger structural spaces he calls "fields" (loosely equivalent to the level of Maclntyre's communal practices). Agents compete within a field for capital, whether material resources or "symbolic capital" such as prestige or authority, and such competition provides the fundamental explanation for scientists' behavior. ${ }^{69}$ Ultimately, according to Bourdieu, "all practices, including those purporting to be disinterested or gratuitous, and hence non-economic, [can be treated] as economic practices directed towards the maximizing of material or symbolic profit." ${ }^{70}$ In contemporary America, such maximization may entail pursuing patents and collaborating with pharmaceutical companies; in sixteenth century Europe, it might have been Tycho Brahe courting patrons for his astronomical research.

Bourdieu's views entered science studies primarily through sociology, notably in Bruno Latour and Steve Woolgar's influential Laboratory Life. Glossing symbolic capital as a broader notion of "credibility," Latour and Woolgar offer the pursuit of credibility as both explanandum and explanans of scientific activity: "The essential feature of this cycle [of credibility] is the gain of credibility which enables reinvestment and the further gain of credibility. Consequently, there is no ultimate objective to scientific investment other than the continual redeployment of accumulated resources." Although Latour and Woolgar insisted that their credibility theory did not attempt to explain scientists'

of Scientists Obscured the Truth on Issues from Tobacco Smoke to Global Warming (New York: Bloomsbury Press, 2010); Robert Proctor, Golden Holocaust: Origins of the Cigarette Catastrophe and the Case for Abolition (Berkeley: University of California Press, 2011).

${ }^{66}$ Ludwig Fritz Haber, The Chemical Industry during the Nineteenth Century: A Study of the Economic Aspect of Applied Chemistry in Europe and North America (Oxford: Clarendon Press, 1958); Ernst Homburg, Anthony S. Travis, and Harm G. Schröter, eds., The Chemical Industry in Europe, 1850-1914: Industrial Growth, Pollution, and Professionalization (Dordrecht: Springer, 1998); Crosbie Smith, The Science of Energy: A Cultural History of Energy Physics in Victorian Britain (University of Chicago Press, 1998); Paul Lucier, Scientists and Swindlers: Consulting on Coal and Oil in America, 1820-1890 (Baltimore: Johns Hopkins University Press, 2010).

${ }^{67}$ Mario Biagioli, Galileo, Courtier: The Practice of Science in the Culture of Absolutism (Chicago: University of Chicago Press, 1993); Richard S. Westfall, The Life of Isaac Newton (New York,: Cambridge University Press, 1993), 273-96.

${ }^{68}$ Steven Shapin, "Ivory Trade," London Review of Books, September 11, 2003, 19. Shapin nonetheless argued that placing commercialization at the center of a university's academic mission threatened the public good.

${ }^{69}$ Pierre Bourdieu, "The Specificity of the Scientific Field and the Social Conditions of the Progress of Reason," Social Science Information 14 (1975): 19-47.

${ }^{70}$ Pierre Bourdieu, Outline of a Theory of Practice (Cambridge: Cambridge University Press, 1977), 183. 
"motivations," they nonetheless discarded motivations as inaccessible and irrelevant to their analysis. ${ }^{71}$ Though few historians have been as explicit as Latour and Woolgar, Bourdieu's framework continues to reappear in sociology of science, despite critiques. ${ }^{72}$

Whereas Bourdieu sees all human activity as a competition for a single good (capital) that takes many forms, we have seen that Maclntyre distinguishes between goods of excellence and goods of efficiency. Maclntyre's goods of efficiency correspond to Bourdieu's notion of capital: money, fame, or authority - goods that can be obtained through many kinds of activities and that are subject to competition. But Maclntyre insists that we also recognize goods of excellence, those that are specific to a particular practice and that advance it by extending its scope, capabilities, or standards. For Bourdieu, such a distinction is nonsense: excellence in a field is not an end in itself but only a means to the end of capital.

Of course, Maclntyre also recognizes that both kinds of goods necessarily accompany a communal practice. Not only are goods of efficiency necessary for developing a practice and sustaining its practitioners, but they flow invariably from the pursuit of a practice itself as a social activity.

Excellence in a practice will bring status and authority; as Bourdieu rightly points out, advancing a scientific practice demands finding what others regard as "important and interesting," and thereby "mak[ing] the man who produces it appear more important and interesting in the eyes of others." 73 Moreover, goods of efficiency are indeed goods, as they enable a practitioner to advance a practice more effectively.

Nonetheless, goods of efficiency always hold the potential to corrupt a practice. Because they can be obtained without the goods of excellence of the practice, anyone focused on them is constantly tempted to subvert the practice: to cheat, to dissemble, to obfuscate, to defraud - in short, to obtain capital by whatever means possible. For the practitioner focused on goods of efficiency, the question is not "How can I advance the practice?" but "What can I get away with?" Moreover, below the level of fraud itself, as goods of efficiency come to dominate a practice, they may alter the goals and norms of that practice, turning it away from its own internal goods.

From the perspective of MacIntyre's practice theory, therefore, fears about the corruption of science reflect the inescapable conflict between goods of excellence and goods of efficiency. Scientific practice has never been "pure," never been free from goods of efficiency. ${ }^{74}$ Yet the calls for pure

\footnotetext{
${ }^{71}$ Latour and Woolgar, Laboratory Life, 198, 207-8.

${ }^{72}$ E.g., Regula Valérie Burri, "Doing Distinctions: Boundary Work and Symbolic Capital in Radiology," Social Studies of Science 38, no. 1 (February 1, 2008): 35-62; Wei Hong, "Domination in a Scientific Field: Capital Struggle in a Chinese Isotope Lab," Social Studies of Science 38, no. 4 (August 1, 2008): 543-70; Mark H. Cooper, "Commercialization of the University and Problem Choice by Academic Biological Scientists," Science, Technology, \& Human Values 34, no. 5 (September 1, 2009): 629-53. One prominent example of the appropriation of Bourdieu by a historian would be Crosbie Smith, The Science of Energy, esp. 3-6; symbolic capital likewise appears frequently in discussions focused on credit or reward, e.g., Mario Biagioli and Peter Galison, eds., Scientific Authorship: Credit and Intellectual Property in Science (New York, NY: Routledge, 2003), 225-79. For an early critique of Bourdieu in science studies, see Karin D. Knorr-Cetina, "Scientific Communities or Transepistemic Arenas of Research? A Critique of Quasi-Economic Models of Science," Social Studies of Science 12, no. 1 (February 1, 1982): 101-30. ${ }^{73}$ Bourdieu, "Specificity of the Scientific Field," 22.

${ }^{74}$ Steven Shapin, Never Pure: Historical Studies of Science as If It Was Produced by People with Bodies, Situated in Time, Space, Culture, and Society, and Struggling for Credibility and Authority (Baltimore: Johns Hopkins University Press, 2010).
} 
science, like Francis Bacon's admonitions about the equally intransigent Idols, should be understood as warnings, as efforts to establish a counter-ideal (however illusory) that would draw practitioners away from the temptations that goods of efficiency present. We should therefore be wary of too-readily dismissing such myths as hypocritical rhetorical gestures designed (as Bourdieu would see them) solely to protect or accumulate symbolic capital. Furthermore, though goods of efficiency may always be present, the potential and form of their threat may vary, mediated by the institutions and structural conditions of the practice itself. Distinguishing between goods of excellence and goods of efficiency can therefore help us better understand Cold War lamentations about the "suburbanization" of physics, nineteenth-century jeremiads about the threats to "pure science," and recent fears about commercialization. ${ }^{75}$ The tension between the two forms of goods evinces a historical dynamic even if it is never resolved, but it can only be understood if we move beyond thinking of scientists exclusively as accumulators of capital. ${ }^{76}$

The nature of goods of excellence (which of course vary across time and space) and the challenges of managing goods of efficiency thus form core foci of a historiography informed by a theory of communal practices. What are the goods of excellence in the practice as articulated by various participants in different times and places? What functions are served by goods of efficiency? How are those goods mediated by specific institutional forms? How (or are) their dangers constrained, and to what extent to they come to dominate or transform a practice? Such questions reflect the ethical commitments of this version of practice theory: an emphasis on the historical shifts in goods of excellence and the crucial distinction between them and goods of efficiency.

\section{Scientific Ethics and Moral Economies}

In MacIntyre's eyes, virtues provide a critical bulwark against the ever-present threat of corruption by goods of efficiency, and more generally, they provide the ethical substructure to a practice. Truthtelling, integrity, courage, justice - such dispositions are essential to sustaining a viable communal practice. On the surface, though, that perspective runs counter to the trajectory of discussions about ethics in Western science and medicine over the last century. As multiple commentators have noted, conscious efforts to elaborate or protect scientific ethics in Europe and the United States have focused on duties, rules, and obligations - a "deontological" approach in philosophical jargon - rather than an approach based on virtues and constitutive goods. In a deontological perspective, the primary goal is not to develop scientists with good character, or reconcile tensions between the aims of science and the aims of other communal practices, but instead to specify "good science" in terms of principles or rules that must be followed. ${ }^{77}$

\footnotetext{
75 David Kaiser, "The Postwar Suburbanization of American Physics," American Quarterly 56, no. 4 (2004): 851-88; Dennis, "Accounting for Research"; Robert Bud, "Introduction to 'Focus: Applied Science,"' Isis 103, no. 3 (September 1, 2012): 515-17. On commercialization, see note 60 above.

${ }^{76}$ For a parallel argument in the analysis of music, see Mark Banks, "Maclntyre, Bourdieu and the Practice of Jazz," Popular Music 31, no. 1 (January 2012): 69-86.

77 Consider, for example, Committee on Science, Engineering, and Public Policy, On Being a Scientist: A Guide to Responsible Conduct in Research: Third Edition (Washington, D.C.: National Academies Press, 2009). A similar emphasis on deontological reasoning exists in international bioethics: Brian Salter and Charlotte Salter, "Bioethics and the Global Moral Economy: The Cultural Politics of Human Embryonic Stem Cell Science," Science, Technology,
} 
Historians of science and medicine have sometimes given a similar emphasis to rules or principles, and not surprisingly so, since such norms are often overt, whether as formal policies or as rationales used to justify actions. Moreover, given the prominence of deontological reasoning, there is a tendency to assume that regularities in behavior are the product of following rules, whether those rules are explicit or tacit. For example, Robert Kohler's influential adoption of E.P. Thompson's "moral economy," focused on the "unstated moral rules" and "moral conventions" that governed the Drosophila community. ${ }^{78}$ Similar accounts indebted to Thompson and Kohler elucidate the rules and conventions (implicit or explicit) that appear to govern interactions among practitioners and the distribution of resources. ${ }^{79}$ (Lorraine Daston's version of "moral economy" - a systematic "web of affectsaturated values" is of a different kind than those derived from Thompson; we will consider her version briefly in the next section. $)^{80}$

Virtue ethicists agree that explicit moral reasoning often draws on rules or principles, but these are understood as heuristics, not iron-clad commands. In the complexities of particular situations, virtue ethicists take a quasi-Wittgensteinian line: the right interpretation of rule cannot come from an additional rule; instead it requires one to be the right kind of person such that one can reason in the right way when confronted with a novel scenario. ${ }^{81}$ In their study of human embryonic stem cell research, for example, Brian and Charlotte Salter highlight the success of a deontological approach to bioethics, but they also note that this success was underwritten by restricting the constitution of bioethics committees in certain ways: medical scientists dominate, while philosophers and theologians form a small minority, and regulatory bodies prize tolerant pluralism and openness to compromise while marginalizing perceived dogmatism. ${ }^{82}$ We can see a similar reliance on virtues to structure community relations and decisions in the valorization of creativity by Cold War American elites or in the emphasis

\& Human Values 32, no. 5 (September 1, 2007): 560-63. For a historical perspective, see M. L. Tina Stevens, Bioethics in America: Origins and Cultural Politics (Baltimore: Johns Hopkins University Press, 2000).

${ }^{78}$ Robert E. Kohler, Lords of the Fly : Drosophila Genetics and the Experimental Life (Chicago: University of Chicago Press, 1994), 12.

${ }^{79}$ W. Patrick McCray, "Large Telescopes and the Moral Economy of Recent Astronomy," Social Studies of Science 30, no. 5 (October 1, 2000): 685-711; Nicolas Rasmussen, "The Moral Economy of the Drug Company-Medical Scientist Collaboration in Interwar America," Social Studies of Science 34, no. 2 (April 1, 2004): 161-85; Bruno J. Strasser, "The Experimenter's Museum: GenBank, Natural History, and the Moral Economies of Biomedicine," Isis 102, no. 1 (March 1, 2011): 60-96.

${ }^{80}$ Lorraine Daston, "The Moral Economy of Science," Osiris, 2nd Series, 10 (January 1, 1995): 4.

${ }^{81}$ We call this "quasi-Wittgensteinian" because we agree with Joseph Rouse that accountability provides the fundamental solution to Wittgenstein's paradox of rule-following. When I encounter a novel situation, there is no right interpretation of a rule hidden in the rule itself or in my previous training. Instead, I discover the right solution only as the result of a dialogue about the right solution with a community by whom I am held accountable. Nonetheless, my success as a community member (one who frequently applies the rules or principles in the right way) depends upon my having come to embody the sensibilities and ways of reasoning common to that community, a process that differs substantively from memorizing formal rules. Nor is it clear that we gain much by claiming that such training is equivalent to learning "tacit" rules that somehow teach me to interpret and apply the explicit rules. Better, in our view and the view of virtue ethics, to insist that memorizing rules and learning to interpret them are two different kinds of processes, and that the latter is far more holistic and dependent on internalizing a wide range of sensibilities and cognitive strategies that are more aptly characterized as dispositions rather than rules. For an example of this perspective, see Rosalind Hursthouse, "Virtue Theory and Abortion," Philosophy \& Public Affairs 20, no. 3 (1991): 223-46.

${ }^{82}$ Salter and Salter, "Bioethics and the Global Moral Economy," 561-62, 567. 
on honor and other gentlemanly qualities among seventeenth century natural philosophers. In both cases, virtues provided exemplary traits but also bounded the communities by marginalizing certain people (alleged dogmatists during the Cold War; women and those outside the landed gentry in the seventeenth century). ${ }^{83}$

Virtues, not just conventions, underwrite communal practices. ${ }^{84}$ That suggests that in addition to looking for regularities in behavior or arguments, historians and sociologists must pay attention to how the sensibilities of practitioners are formed, what models they are given to emulate, and what dispositions are valued. Indeed, one of the great strengths of Kohler's work on Drosophila labs is that despite his emphasis on conventions, he develops a close study of pedagogy and lab practices to show how participation in the Drosophila community shapes practitioners themselves. Paying attention to the cultivation of virtue requires integrating the new interest in pedagogy (especially a Foucaultian emphasis on shaping the self) with an extension of the analyses Steven Shapin has developed as a Social History of Truth for seventeenth-century England - e.g., the type of analysis Andrew Warwick has undertaken for Cambridge mathematical physicists. ${ }^{85}$

\section{Values and the Analysis of Normative Practices}

Discussions of "values in science" can imply that values are one component of science, ingredients that are (necessarily) mixed in with other, non-value-laden aspects of scientific research. By contrast, once we adopt a MacIntyrean view of science as a communal practice, we can see that every aspect of science is necessarily normative. ${ }^{86}$ Selecting a telos is a normative act, and because communal practices have teloi to which they are accountable, normativity thereby pervades all parts of the practice. Good science ought to look like such and such; good scientists ought to have these dispositions so as to reach those goals; good scientists ought to use these methods and develop these tools, and so forth.

Communal practices thus have a holistic normativity-not that the choice of a telos causally determines other aspects of the practice, but rather that the overall accountability of the practice creates pressure for the components of a practice to function together, and at a minimum always leaves them open to normative challenge.

Consider the opening vignette to Lorraine Daston and Peter Galison's Objectivity. In 1894, the British physicist Arthur Worthington succeeded in photographing the splash of mercury drop as it hit a plate and was stunned by its irregularity. Comparing the photographs to the symmetrical drawings of the same phenomena he had previously published, Worthington now rejected the latter as idealized simplifications. Yet Daston and Galison emphasize that the photographs did more than reveal to Worthington the limits of his own perception. Instead, turning back to his notebooks, Worthington

\footnotetext{
${ }^{83}$ Jamie Cohen-Cole, "The Creative American: Cold War Salons, Social Science, and the Cure for Modern Society," Isis 100, no. 2 (June 1, 2009): 261; Shapin, A Social History of Truth, 65-125. For an analysis of honor, gender, and sex, see Robert A. Nye, Masculinity and Male Codes of Honor in Modern France (University of California Press, 1998).

${ }^{84}$ Söderqvist, "Virtue Ethics and the Historiography of Science," 47-50.

${ }^{85}$ Warwick and Kaiser, "Kuhn, Foucault, and the Power of Pedagogy"; Shapin, A Social History of Truth. The links between pedagogy and virtues (though not always theorized as such) appear strongly in Warwick, Masters of Theory, esp. chap. 4.

${ }^{86}$ We are thus led, by a different route, to the same conclusion as the philosopher Joseph Rouse, who has insisted that all practices are constituted by normativity: Rouse, How Scientific Practices Matter.
} 
discovered that his original drawings had also displayed asymmetries, irregularities that he had effaced in constructing his published representations. In Daston and Galison's depiction, Worthington's encounter with droplet photographs led him to re-envision the goals of scientific representation, moving from "truth-to-nature" (with its idealized forms) to "mechanical objectivity," a shift that also entailed new virtues such as self-restraint. Mechanical objectivity thus offered new goals for scientific research, a new understanding of the ideal scientist, and a new list of appropriate experimental techniques. ${ }^{87}$ It was a "moral economy" in the sense that Daston (departing from Thompson) had defined it in 1995: a systematic logic of "affect-saturated values." ${ }^{88}$ Yet Worthington's move from one moral economy to another arose not from abstract reflection on the proper telos of physics but from his adoption of new research practices (photography rather than drawing).

Holistic normativity does not imply rigid determination, as though specifying one aspect of a communal practice would force all other components to adopt particular forms. Still less does it imply homogeneity across the practice. We have already noted that participants in a practice may not agree on the telos for that practice, and even if they did settle on a particular definition ("Good research in molecular biology ought to fulfill these criteria...."), that definition would still need to be interpreted and applied to concrete situations. As Wittgenstein's critique of rule-following demonstrates, rules (such as our definition of good molecular biology) are never self-interpreting, and thus there is always space for slippage between the components of a practice. Each component of a practice bears a logical relationship to other aspects (we can see how it fits, or at least might have fit at one time), but it is also underdetermined by the rest of the practice.

In the familiar case of the "underdetermination of theory by evidence," historians from Kuhn onwards have argued that context helps us understand (renders intelligible) why particular people adopted one theoretical interpretation rather than another. Likewise, practice theorists insist that any given practice is mutually shaped by the web of other practices with which it is entangled. Every historian of science participates in an array of practices and may have an idiosyncratic interpretation of each; these practices invariably impinge on their activities as historians, and thereby help shape what they think good history ought to be, what qualities make for a good historian, and so forth. To return to our example of Arthur Worthington, Daston and Galison emphasize that it was not the camera per se that pushed Worthington and other nineteenth-century scientists toward mechanical objectivity. Instead, their use and interpretation of the camera was shaped by a broader nineteenth-century practice of photography (including, for example, an understanding of what good photography ought to be and how it related to older forms of representation), the redefinition of the practice of science vis-àvis the practice of art, and their immersion in post-Kantian philosophical views of the self and ethical practices. ${ }^{89}$

This view resonates with Matthew Stanley's concept of "valence values," i.e., values that may be shared (if only temporarily) across different communities as practitioners engage in both domains and seek to make them coherent. As Stanley demonstrates in the case of British physicist Arthur Eddington, dual participation may reinforce the significance of certain virtues, norms, or teleological goals that are

\footnotetext{
${ }^{87}$ Daston and Galison, Objectivity, 11-16.

88 Daston, "The Moral Economy of Science," 3-5.

${ }^{89}$ Daston and Galison, Objectivity, 115-251.
} 
commonly shared across two communal practices. In other cases, such as Eddington's Quaker-inspired commitment to internationalism during the First World War, values drawn from one practice might place a practitioner on the margins of a second. ${ }^{90}$ Conversely, at times one subset of practitioners might seize upon or redefine particular virtues, norms, or goals in order to force the incompatibility of two practices, much as Thomas Huxley and his allies sought to make naturalism the center of Victorian science and hence cleave it from Victorian religion. ${ }^{91}$ Hicks develops a similar notion, the idea of a joint practitioner who inhabits two communal practices and translates insights and critiques between them, and argues that the critical scientific contributions of feminist scientists can be understood in terms of this kind of joint practice. ${ }^{92}$

As historians, therefore, one of our tasks is to undertake a holistic study of normative practices. We should be attuned to how goals, standards, and methods can migrate from one practice to another; how virtues promoted in one domain come to serve or characterize a second; how conflicts within a community can be traced in part to its members simultaneously being part of different arrays of other practices; and so forth. We can ask what standards are used, what goals are valorized, what qualities are celebrated or condemned, what tools are used and how - seeking to elucidate systematic relationships among these features and between them and other practices, and knowing that all features of a practice are normative by the inherent normative character of communal practices themselves, linked to their teleological character.

Virtues (valorized dispositions) are thus embodied values, formed through pedagogy. They are logically related to the goods of excellence in a communal practice, and just as the adoption of new goods of excellence can lead to the re-evaluation of a practices virtues, so too can the importing of new virtues from other practices (via dual membership) transform the goods of excellence. Both the goods of excellence of a practice and the means of reaching those goods (virtues and methodological norms) can be the subject of conflicts within a communal practice as members struggle to relate it to other practices, either by bringing them into coherence or seeking to pull them apart.

\section{Virtues \& the Ethos of Science}

In MacIntyre's account, virtues serve three functions: to enable individuals to achieve excellence in a practice, to protect the practice from the threat of corruption by goods of efficiency, and to be constitutive components of the good human life..$^{93}$ In other words, virtues have instrumental value for enabling and protecting the goods of excellence in a practice, but they also have intrinsic value in themselves. For example, courage aids the soldier or citizen, but for Maclntyre (and the virtue ethics tradition more broadly), it is equally important to fulfilling the telos of a good life, that is, important to being a good human.

\footnotetext{
90 Matthew Stanley, Practical Mystic: Religion, Science, and A.S. Eddington (University of Chicago Press, 2007), esp. 7-10.

${ }^{91}$ Matthew Stanley, Huxley's Church and Maxwell's Demon: From Theistic Science to Naturalistic Science (Chicago: University of Chicago Press, 2015).

92 Hicks, “A New Direction for Science and Values," esp. 3291; Daniel J. Hicks, "Scientific Practices and their Social Context" (Ph.D. dissertation, University of Notre Dame, 2012), sec. 5.2.

${ }^{93}$ Macintyre, After Virtue, 191-94.
} 
To see why, we can return to our previous discussion of goods of excellence. If a practice has goods with intrinsic value, that can only be because practitioners embed those goods within broader views of what constitutes a meaningful life or way of being in the world. To claim that helping other people or understanding more about the cosmos has intrinsic value is equivalent to stating that the pursuit of such activities constitutes part of living an excellent life. Accordingly, to be the kind of person who can and does pursue such activities well is precisely to be an excellent human.

At least in the case of science, though, this abstract line of reasoning faces certain difficulties. First, if excellent science requires possession of certain virtues and those same qualities also contribute to being an excellent human being, that implies that excellent scientists ought to exemplify at least some of the qualities of excellent humans. Yet, as Steven Shapin has demonstrated, we have come to accept the moral equivalency of even the "best" scientists: far from being distinct (much less superior) moral creatures, we see scientists as exhibiting the same kinds of flaws as everyone else. ${ }^{94}$ Indeed, a seemingly-endless series of sexual harassment scandals in academic science, in fields as diverse as astronomy and ethology, seems to show that "excellent" scientists can be deplorable human beings.

Here we need to be clear on several points. First, one can excel in some areas and not others, and we must remember that the Aristotelian notion of virtue-as-excellence is far broader than our colloquial use of "moral," encompassing cognitive dispositions as well as those related to the treatment of other people. One can be an incredibly adept and meticulous exoplanet researcher who nonetheless sexually harasses graduate students.

Second, the virtue ethicist notion of the unity of the virtues can also be helpful. ${ }^{95}$ According to this view, the virtues require each other for their highest or most authentic realization. The serial harasser may achieve outstanding work in his research, narrowly construed; but he will fail as a teacher and mentor, driving promising students away from the field and tempting his colleagues into dishonesty and injustice in order to protect the reputation of the department or university. Accordingly, he will be damaging the practice as a whole, and thus could not truly be considered an excellent practitioner, even on the narrow terms of the practice itself.

A deeper objection may be that many scientists themselves have eschewed claims to moral or ethical authority. Max Weber, after all, famously declared that a scientist was not "a prophet or a savior." Yet what appears to be a disavowal of ethical authority reveals itself on closer inspection to be the promulgation of an alternative ethics. Though Weber discarded the mantle of prophet, he nonetheless argued that engaging in science meant taking a normative stance, just not the in the guise of a prophet. The proper scientist would press an individual to "clarify" his own thought, to consider its coherence and the ramifications of its presuppositions and choices, and thus to "force..., or at least...help him, to give himself an account of the ultimate meaning of his own conduct." 96 Though science did not provide objective ethical judgments, it was nonetheless fundamentally oriented toward ethics. Indeed, it embodied an ethos that prized self-knowledge, rigor, and intellectual integrity. To be a scientist was to take a stand in the conflict of values.

\footnotetext{
${ }^{94}$ Shapin, The Scientific Life, 21-91.

${ }^{95}$ Hursthouse, On Virtue Ethics, chap. 7; Annas, Intelligent Virtue, chap. 6.

${ }^{96}$ Max Weber, "Science as a Vocation," in From Max Weber: Essays in Sociology, ed. H. H. Gerth and C. Wright Mills (New York: Oxford University Press, 1946), 153, 152.
} 
For a rather different example, we might consider Richard Feynman. Feynman, of course, denied that scientists had any special moral qualities: he avoided political engagement and delighted in flouting conventional mores, whether experimenting with drugs or frequenting strip clubs. Indeed, in a notorious chapter of his memoirs, Feynman describes calling a woman "worse than a whore" for refusing to offer sex after he bought her sandwiches. ${ }^{97}$ Yet Feynman found himself equally driven to comment on "the value of the science I had dedicated myself to," a value that he found in its "grand adventure" -- a "particular type of religious experience" - but also in its facility for cultivating a "philosophy of ignorance" and its emphasis on "freedom." 98 Feynman's many public lectures were of course designed to depict and valorize that form of life, with its consonant virtues (cast in a heterosexual, masculinized frame): irreverence, play, humor, wit, curiosity, daring-as well as a faux-naïve objectification of women and commodification of sex. Feynman's self-conscious rejection of conventional mores reflected his own efforts to build an alternative ethos, one that attracted numerous young male physicists of his era even as its sexist dimensions damaged many women.

Neither Weber nor Feynman are unique in this regard. Talk of the split between science and ethics reveals more about our impoverished notion of "ethics" than it does about science. Insofar as scientists treat their work as having intrinsic value-as being worth pursuing because of the excellence of its own goods - that implies that being a scientist is a vocation, a form of life with rich ethical value, even if we disagree with aspects of the ethos that certain scientists expounded. ${ }^{99}$ As Chad Wellmon has argued (drawing explicitly on MacIntyre), the German scholars who created the conception of the modern research university at the turn of the nineteenth century understood the pursuit of Wissenschaft as just such a vocation, nor has that legacy entirely disappeared (much as it may be under assault). ${ }^{100}$ As historians, therefore, we should aim to explicate the ethical ends associated with a scientific practice in a given time and place, to understand its aims and virtues insofar as it remains a communal practice. Moreover, because an ethos invariably takes its form through entanglements with multiple practices, we should explore how the ethos attributed to specific scientific fields intersects with surrounding practices and their attendant virtues, such as democratic ideals in the twentieth century or spiritual practices in the seventeenth, and indeed how it may clash with competing practices. ${ }^{101}$ As Matthew Stanley has put it, "When we examine a scientific project or a religious task, we should look for the ought that drives it: What values make this task worth doing?"102

\footnotetext{
${ }^{97}$ Richard P. Feynman and Ralph Leighton, "Surely You're Joking, Mr. Feynman!": Adventures of a Curious Character, ed. Edward Hutchings (New York: W. W. Norton, 1985), 188-90; Christopher Sykes, ed., No Ordinary Genius: The Illustrated Richard Feynman (New York: Norton, 1994), 89-123.

98 Richard P. Feynman, What Do You Care What Other People Think? Further Adventures of a Curious Character, ed. Ralph Leighton (New York: Norton, 1988), 239, 243, 248.

${ }^{99}$ Söderqvist, "Virtue Ethics and the Historiography of Science," 50-56.

100 Wellmon, Organizing Enlightenment.

${ }^{101}$ Andrew Jewett, Science, Democracy, and the American University: From the Civil War to the Cold War (New York: Cambridge University Press, 2012); Jones, The Good Life in the Scientific Revolution.

102 Stanley, Practical Mystic, 5.
} 


\section{The Historicity of Practices, and the History of Science}

For Maclntyre, communal practices are fundamentally historical enterprises. They are embedded in particular contexts, and of course they change over time. But their historicity also lies at a deeper level: communal practices continually and necessarily retell, restructure, and reinterpret their own history, what MacIntyre labels their "tradition." To be a part of a communal practice means to place oneself within a tradition, to interpret the past and assume a specific relationship to it. The bounds of that tradition are not fixed, nor does it preserve some essential core for all time. Instead, in Maclntyre's terms, "a living tradition...is an historically extended, socially embodied argument, and an argument precisely in part about the goods which constitute that tradition."103

The historicity of communal practices arises from their normative character. Because a practice has goals, teloi, the status of that practice relative to its standards can always be evaluated vis-à-vis any other moment as better, worse, or indifferent. And of course such reevaluation constantly occurs, since that is the only way to assess whether the practice is making progress, remaining static, or regressing, and hence the only way to judge whether and in which ways the practice ought to change.

Simultaneously, the goals of the practice themselves are always open to scrutiny and debate, both because the practitioners themselves may not (and almost assuredly do not) share precisely the same conception of the practice and because any given practice is constantly entangled with surrounding practices that are themselves historical products. But of course these competing conceptions of the practice also entail competing standards and goals, and therefore competing ways of interpreting and ordering the past as well as the present. Normative battles over the present thus entail, and are enacted through, arguments about history. ${ }^{104}$

We are of course familiar with this phenomenon in science. Despite many scientists' dismissal of historical study, they craft historical narratives constantly. ${ }^{105}$ The literature review - a standard and necessary component of any contemporary scientific paper is precisely such a narrative: an attempt to order the past by picking out its relevant elements and arranging them into a coherent story with a recognizable form - whether of incremental progress, stagnation, divergence, decline, or something else-into which the current project now appears as progress toward the telos explicitly or implicitly identified in the paper itself. Rarely will two competing scientists share exactly the same vision of the past, even if the dispute is localized to the proper narrative for a single experiment. To be a scientist is to be a historian, just as in any communal practice, for conflicts over the present and future of a practice are equally conflicts over its past.

Where then does that leave the professional historian of science, those of us who have chosen to write the history of sciences as our own peculiar vocation? For decades, historians of science have drifted from the practice of contemporary science. Historical research demands skills and knowledge that are not part of scientific training and rarely valued by scientists themselves, and it has become unusual (rather than common) for historians to have advanced degrees in the scientific fields that they

\footnotetext{
103 Maclntyre, After Virtue, 204-25, esp. 222.

${ }^{104}$ Maclntyre, "Epistemological Crises, Dramatic Narrative and the Philosophy of Science."

105 Sharon Traweek, Beamtimes and Lifetimes: The World of High-Energy Physics (Harvard University Press, 1992), $77,86-87,93$.
} 
study. As for scientists themselves, few are beating down historians' doors to glean the latest historical insights.

Yet if science is a communal practice as described above, then the history of science is always a potential intervention into the practice of contemporary science. Just as arguments over the present always entail reinterpretations of the past, so does every novel historical account potentially demand a re-accounting of the present, and the history of science thus confronts contemporary practice, whether to reinforce it, challenge it, or simply open new possibilities that (ipso facto) force us to ask why the world looks like this rather than that. "History," as Thomas Kuhn wrote in the opening sentence of Structure, "if viewed as a repository for more than anecdote or chronology, could produce a decisive transformation in the image of science by which we are now possessed." 106

Of course, scientists are unlikely to peruse Isis in search of new research hypotheses or to cite historians of science routinely in their literature reviews. Yet the core revelation of the practice turn, of the turn from identifying science as disembodied knowledge to science as an activity, was recognizing that all the features of that activity (such as pedagogy, instruments, experimental techniques, emotional dispositions, cognitive habits, self-professed goals, and so forth) were not the context for science; they constituted science in a given time and place. Precisely because that was not "the image of science by which we [were] now possessed," it became a goal, one might even say an ethical goal, of historians of science to raise those issues to consciousness for both scientists and non-scientists alike. In that respect, just as feminists seek to highlight gender, just as postcolonialists attend to imperialism and marginalized voices, those persuaded by MacIntyre's analyses will emphasize the struggles to define the norms and patterns of accountability of a practice, the transformations in its goods of excellence, their precarious balance with goods of efficiency (and perhaps their disappearance), the critical place of virtues in science (and their changing character), and the competing and shifting visions of an ethos that links the elements of scientific practice into a meaningful life (or not). Nor is such an emphasis incompatible with many other ethical stances, including that of feminism or postcolonialism.

How to make such interventions into scientific practice effective, of course, is another matter. For many of us the path may lie through our undergraduate teaching-especially efforts to reach majors in science, engineering, and medicine. Others have positioned themselves as public intellectuals, writing for general audiences or working directly in science policy or with scientists themselves. ${ }^{107}$ Whichever institutions we work within, and whatever media we use to communicate, effective intervention will require us to remain cognizant of the ethics entailed by our historiographic decisions, even the adoption of seemingly prosaic terms such as "practice." Ethics are not something we add to our historical work; they are embedded within it, and conscious efforts to elaborate ethical frameworks can thereby enhance our self-understanding of our work. The ethics we choose will shape the stories that we tell, just as those stories animate the ethics-and perhaps even put them to the test.

\footnotetext{
${ }^{106}$ Kuhn, The Structure of Scientific Revolutions, 1.

${ }^{107}$ For a recent reflection on such a role, see http://hssonline.tumblr.com/post/137625764140/dr-largent-wentto-washington.
} 
Figure 1: Sentences and citations containing "practice(s)" in research articles within select journals, 1960 - 2010

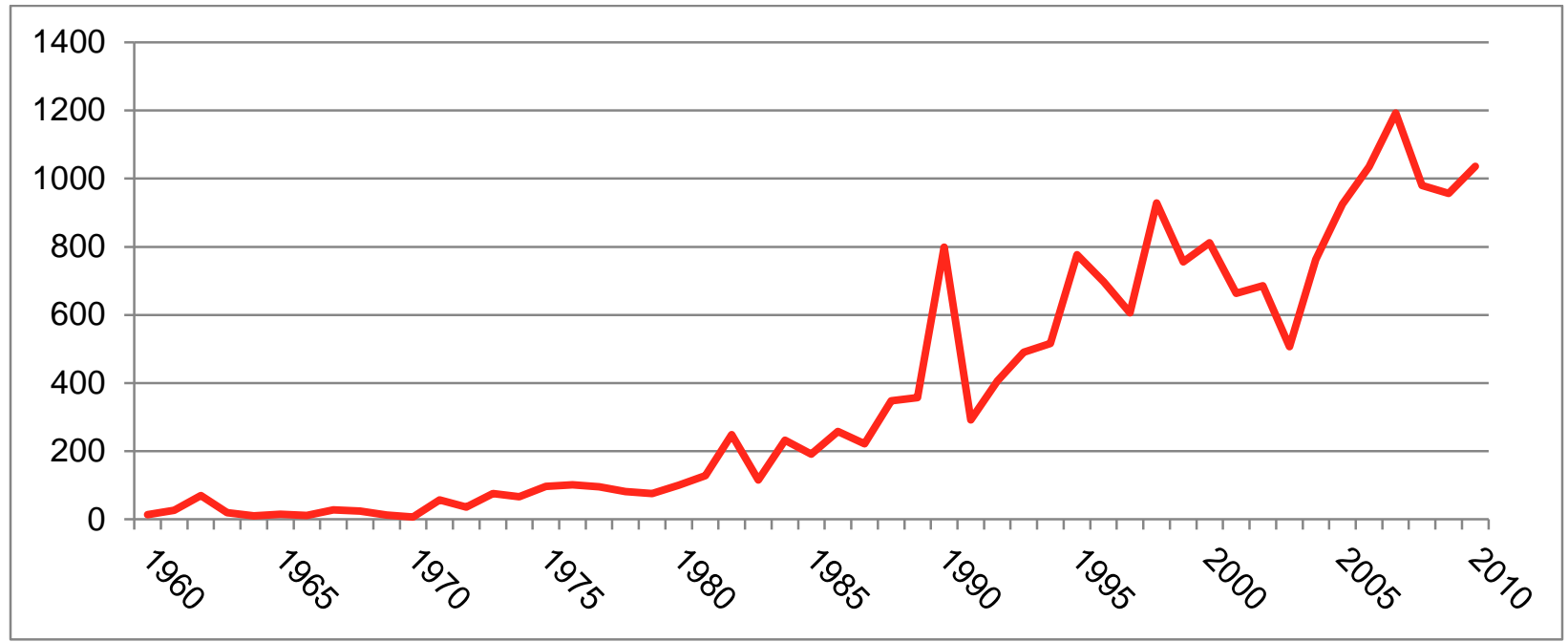

Figure 1 depicts the rising number of sentences and citations that use the terms "practice" or "practices" in research articles published within five major, English-language journals that cover the history of science: Isis, Osiris, British Journal for the History of Science, Social Studies of Science, and Studies in the History and Philosophy of Science. These journals were chosen for their significance in Anglo-American scholarship, generalist coverage (not focused on a specific scientific field), and ease of access for textual analysis. Usages of "practice" with little conceptual content (e.g., "in practice," common practice," "to practice," etc.) were excluded, as were instances that clearly referred to domains other than science (e.g., "religious practice," "medical practice," etc.). ${ }^{108}$

${ }^{108}$ Excluded phrases include: into practice, in practice, common practice(s), to practice, medical practice(s), clinical practice(s), private practice(s), psychiatric practice(s), practice(s) of psychiatry, practice(s) of medicine, legal practice, practice of law, religious practice(s). 
Figure 2: Percentage of research articles with at least five sentences or citations using "practice," Isis, 1960 - 2010

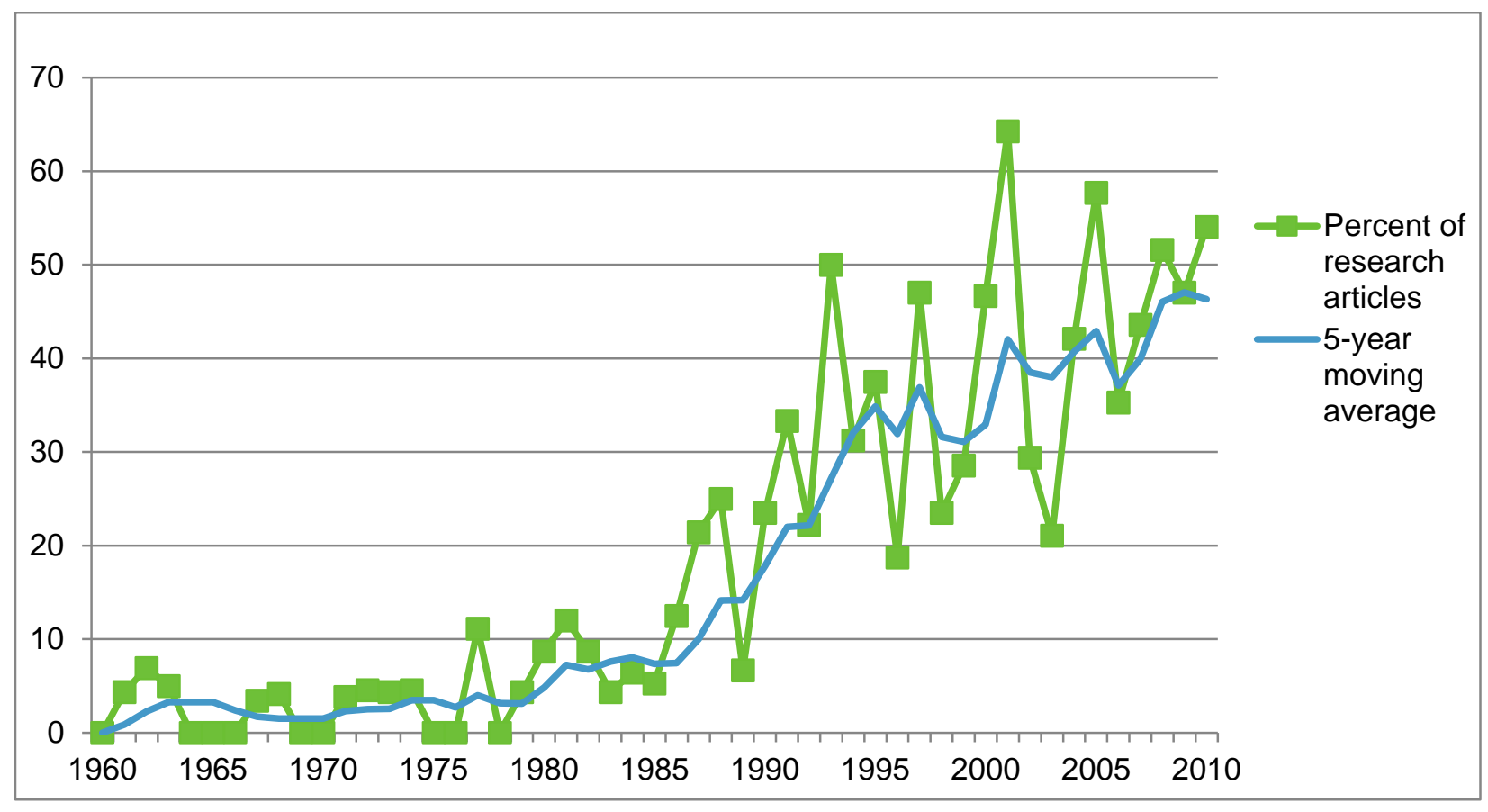

We followed JSTOR's categorization of research articles as a first approximation, but then eliminated any articles less than five pages long, as well as eloges, letters to the editor, and short responses. 